\title{
両端拘束一方向性合成スラブの荷重変形特性に関する研究 EXPERIMENTAL STUDY ON THE LOAD-DEFLECTION PROPERTIES OF RESTRAINED ONE-WAY COMPOSITE SLABS
}

\author{
森村＼cjkstart毅*, 大廣麻里**, 大田和彦***, 在永末徳* \\ Tsuyoshi MORIMURA, Mari OHIRO, Kazuhiko OHTA \\ and Suenori ARINAGA
}

\begin{abstract}
In this report we described on obtaining the load-deflection curve of the restrained one way composite slabs and compared the curve of calculated results with the curve of experimental values, then investigated.
\end{abstract}

As a result, the curve of a calculation value showed a tendency to match a curve of experimental value well approximately.

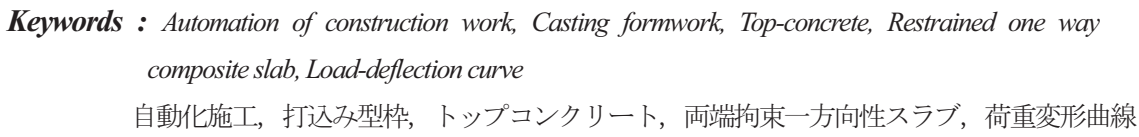

\section{1. はじめに}

近年の鉄筋コンクリート構造の発展は型枠技術の進歩なくしては 成り立たなかったと考えられる。特に最近, 型枠技術の進歩は目覚 しいが, それと密接な関係として論じられているものに地球環境破 壊や資源の有効利用の問題がある。現在なお型枠材料として重要な 役割を占めている合板は多量の熱帯雨林を伐採して作られるため, その行為が地球規模の環境破壞を起こす要因の一つにあげられてい る。

そのため我が国においても早急に合板型枠を見直し，合板型枠の 代替品の開発を急がなければならず，現在では国土交通省を始め各 建設業界においても積極的に研究開発が行われている。また，それ と同時に建設業界に深刻な問題を投げかけているものに型枠専門工 の高齢化や技能労働者不足がある。

従って, 21 世紀の今日においては, 将来起こりうるであろう上述 の諸問題等について対処しておく必要があり, 早急に建設工事全体 の抜本的な解決策を考えておかなければならない。それが今日省力 化やシステム化の必要性が要請されている所以である。

その抜本的な解決策の一環として現在国土交通省が進めているも のに情報化施工や自動化施工がある。特に自動化施工の方面におい ては高曲げ無機材料によって作られた打込み型枠を用いて無支保工, 支保工の簡略化およびコンクリート打設後早期に資材の運搬・ス卜 ック・据え置きのための自動型施工機械が走行できる床構法システ ムの開発がある。この床構法システムの開発は, $3 \mathrm{~K}$ の代名詞にもな っている建設現場にも週休 2 日制の導入を狙ったものである。打込 み型枠材を用いた床スラブは型枠材を梁間に掛けて，上からトップ
コンクリートを流し込んで床スラブを形成するため一種のハーフス ラブ形式の合成スラブである。型枠材自体は中空孔を有した一方向 性のものであるが，配筋を施した後トップコンクリートを打込むと 大梁で周辺が拘束されて二方向性の力学的性質を持つ合成スラブに なると考えられる。

筆者は，長年その実用化に向けた研究開発に取り組んできた。そ の一環として筆者等は過去 ${ }^{1) ~ 4)}$ ，上述の高曲げ無機材料の打込み型 枠材 (以後型枠材と称す) を用いて両端拘束一方向性合成スラブ（以 後合成スラブと称す）の実物大実験を行ってきた。

そこで本研究は，合成スラブの破壊メカニズムおよび荷重変形特 性を明らかにすることを目的に解析的研究を行い，その解析結果と 過去行った実験結果の比較検討を行ったものである。なお，解析で 用いた載荷方法は実験と同じ 4 等分割線上の 2 点均等載荷で行った。 また，以下の論文では工学単位を用いている。

\section{2. 基本仮定}

合成スラブの破壊メカニズムおよび荷重変形特性を明らかにする ためには，合成スラブの荷重変形曲線を解析的に求めること（以後 解析曲線と称寸）が非常に重要である。以下には，解析曲線を求め るために，以下の基本仮定を用いた。

1) コンクリート, 鉄筋および型枠材の応力度一ひずみ度 $(\sigma-\varepsilon$ 曲線）は完全弾塑性と考え, 図1(a)(b)(c)とした。

2) 部材断面は平面保持の仮定が成立する。

3) 面内圧縮力による軸方向変形は弾性範囲とする。

4) コンクリートと型枠材は一体化している。

\footnotetext{
* 近畿大学工学部 教授 $\cdot$ 工博

** 近畿大学 大学院生

*** 近畿大学工学部 准教授・工博
}

Prof., Dept. of Architecture, Faculty of Eng., Kinki Univ., Dr. Eng. Graduate Student, Dept. of Architecture, Kinki Univ.

Assoc. Prof., Dept. of Architecture, Faculty of Eng., Kinki Univ., Dr. Eng. 
5) 中空孔を持つ型枠材は図 2 のような等価な中実型枠材とする。

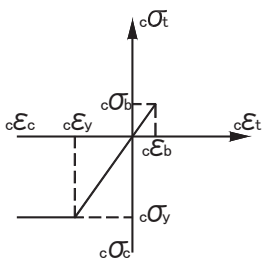

(a) コンクリート

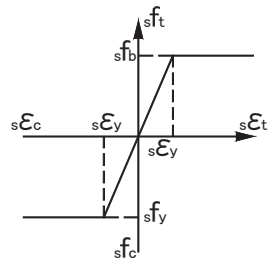

(b) 鉄筋

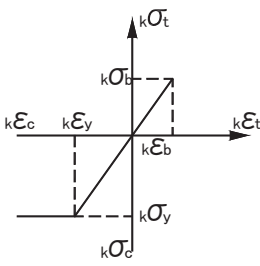

(c) 型枠材
図 1 各材料の応力度一ひずみ度曲線

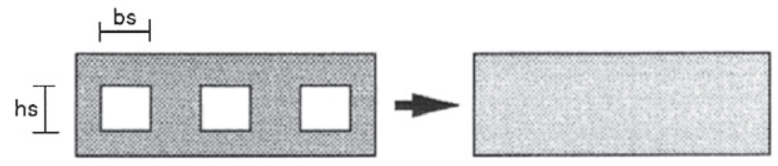

(a) 中空断面

(b) 中実断面

\section{3. 解析方法}

一般のスラブは，二方向性として用いられるが，図 3 に示すよう に二方向性スラブは一方向性スラブの集合体と考えることができ， 一方向性の性質を明らかにすることによって，その結果が二方向性 にも適用できると考える。したがって, 以下では一方向性の合成ス ラブの解析曲線式の誘導方法について述べる。

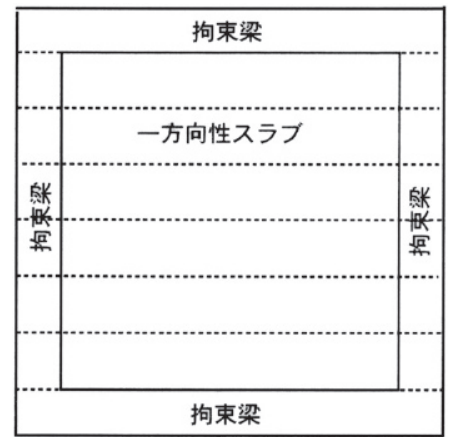

図 3 周辺拘束二方向性スラブ

\section{1 解析曲線式の誘導}

合成スラブは型枠材の上にトップコンクリートを打込んだもので あるため，型枠材とコンクリートが必ずしも一体化するとは限らな い。境界面の性状を考慮する必要はあるが, 本研究では一体化した 合成スラブと考えて解析曲線式の誘導を行う。また, 式の誘導に際 しては実験時の試験体の曲げひび割れ進行状態を参考として下記に 示す 3 段階に分けて解析曲線式を誘導する。

(1) 第 1 段階一両端部コンクリートの曲げひび割れ荷重時

(2) 第 2 段階一曲げひび割れ荷重以後, 中央型枠材の曲げひび割れ 荷重まで

(3) 第 3 段階一中央型枠材の曲げひび割れ荷重以後終局耐力まで 以下では，曲げひび割れ伸展状態順に解析曲線式の誘導を行う。 1) 準備計算

型枠材は基本仮定 5)の図 2(a)で示したように中空断面を持つが， 解析では図 2(b)の置換中実断面（以後中実断面と称す）として用い

るため, 解析で用いる中実断面の曲げ剛性 $\left(E_{k} I_{k}\right)$ は中空断面の曲げ 剛性 $\left(E_{k h} I_{k h}\right)$ と等価なものに置換して求めた式(1)を用いる。

$$
E_{k} \varepsilon_{b} Z=E_{k h} \varepsilon_{b} Z\left(1-\alpha^{3} \beta\right)
$$$$
E_{k}=\left(1-\alpha^{3} \beta\right) E_{k h}
$$

ここで, $\alpha=h_{s} / h, \quad \beta=m b_{s} / B, h$ : スラブ厚, $B$ : スラブ幅, $h_{s}$ : 孔丈, $b_{s}: 1$ 個分の孔幅, $m$ : 孔個数

2) 端部曲げひび割れ荷重時

この段階は合成スラブ両端部上端のコンクリート部分が曲げひび 割れモーメントに達して曲げひび割れを生じる時点を指し，その時 の合成スラブ両端部と中央部断面の応力状態およびひずみ分布状態 は図 4 のように示される。
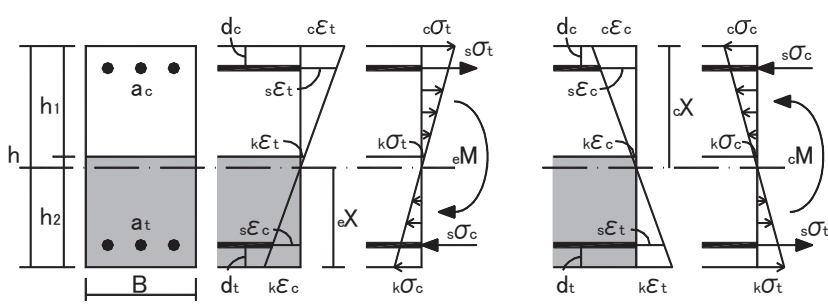

(a) 断面図 (b) 端部の応力度一ひずみ度分布 (c) 中央部の応力度一ひずみ度分布

図 4 端部曲げひび割れ以前の応力状態図

図 4(b)から, 端部断面のつり合い式 $C-T=0 （ C$ : 圧縮合力, $T$ : 引張合力）より, 端部の中立軸距離 $e X$ を求めると,

$$
e_{e} X=\frac{h^{2}+(k-1) h_{2}^{2}+2(n-k) h p_{t} d_{t}+2(n-1) h p_{c}\left(h-d_{c}\right)}{2\left\{h+(k-1) h_{2}+(n-k) p_{t} h+(n-1) p_{c} h\right\}}
$$

同様に，図 4(c)から，中央部断面のつり合いより中央部の中立軸 距離 $c X$ を求めると次式になる。

$$
{ }_{c} X=\frac{k h^{2}-(k-1) h_{1}^{2}+2(n-k) h p_{t}\left(h-d_{t}\right)+2(n-1) h p_{c} d_{c}}{2\left\{k h-(n-k) h_{1}+(n-k) h p_{t}+(n-1) h p_{c}\right\}}
$$

よって，端部および中央部断面に作用する曲げモーメント $e_{e} M$ は 次式で求まる。ここで求める $e M$ は端部曲げひび割れモーメント $M_{c r}$ となり ${ }_{e} M=M_{c r}$ で表せる。

$$
\begin{aligned}
e_{e} M= & \frac{B E_{c c} \varepsilon_{t}}{3\left(h-{ }_{e} X\right)}\left\{3(n-1) h p_{c}\left(h-{ }_{e} X-d_{c}\right)^{2}+3(n-k) h p_{t}\left({ }_{e} X-d_{t}\right)^{2}\right. \\
& \left.+k_{e} X^{3}+(k-1)\left(h{ }_{2}{ }_{e} X\right)^{3}+\left(h-{ }_{e} X\right)^{3}\right\}
\end{aligned}
$$

また，図 5 の $M$ 図より

$$
\text { c } M=\frac{e M}{3}
$$

ここで, $n=E_{S} / E_{c}, \quad k=E_{k} / E_{c}, \quad h_{1}, h_{2}$ : コンクリート厚と型枠 材厚, $E_{c}, E_{s}, E_{k}$ : コンクリート, 鉄筋及び型枠材のヤング係数

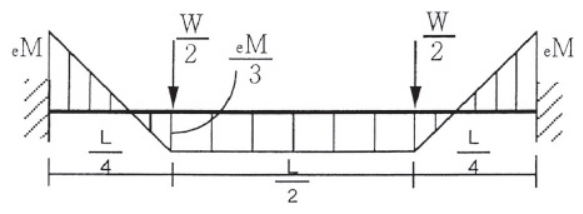

図 5 端部曲げひび割れ以前の曲げモーメント図

次に，両端部が曲げひび割れモーメントに達するときの合成スラ ブの中央たわみ量 $c \delta_{c r}$ は, 図 6 のモールの定理より次式で求められ る。 
${ }_{c} \delta_{c r}=\frac{e M L_{1}\left(L / 2-L_{1} / 3\right)}{2 E_{c e} I}-\frac{{ }_{c} M L_{2}\left(L / 2-a+L_{2} / 3\right)}{2 E_{k c} I}-\frac{{ }_{c} M(L / 2-a)^{2}}{2 E_{k c} I}$

なお，端部と中央部の断面 2 次モーメント $e I, c I$ は

$$
\begin{aligned}
e I= & \frac{B_{e} X^{3}}{3}+(n-k) p_{t} B h\left({ }_{e} X-d_{t}\right)^{2}+\frac{B\left(h-{ }_{e} X\right)^{3}}{3} \\
& +(n-1) p_{c} B h\left(h-{ }_{e} X-d_{c}\right)^{2} \\
c I= & \frac{B_{c} X^{3}}{3}+(n-1) p_{c} B h\left({ }_{c} X-d_{c}\right)^{2}+\frac{B\left(h-{ }_{c} X\right)^{3}}{3} \\
& +(n-k) p_{t} B h\left(h-{ }_{c} X-d_{t}\right)^{2}
\end{aligned}
$$

ここで, $L_{1}={ }_{e} M L / 4\left({ }_{c} M+{ }_{e} M\right), \quad L_{2}={ }_{c} M L / 4\left({ }_{c} M+{ }_{e} M\right)$, 支点と荷 重点の距離 $a: L / 4=L_{1}+L_{2}$

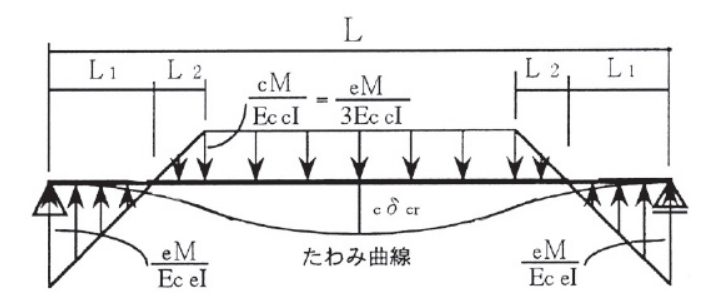

図 6 端部曲げひび割れ以前のモールの仮想荷重図

よって, 求める曲げひび割れ時の総荷重 $W_{c r}$ は図 5 より

$$
W_{c r}=\frac{32_{e} M}{3 L}
$$

また, 端部曲げひび割れ荷重以後の計算に用いる曲げひび割れ荷 重時の端部と中央部の圧縮ひずみ $k \varepsilon_{c},{ }_{c} \varepsilon_{c}$ の初期值は図 4(c)より次 式で表される。

$$
\begin{aligned}
& { }_{k} \varepsilon_{c}=\frac{{ }_{e} X_{c} \varepsilon_{t}}{h-{ }_{e} X} \\
& { }_{c} \varepsilon_{c}=\frac{{ }_{c} X{ }_{k} \varepsilon_{t}}{h-{ }_{c} X}
\end{aligned}
$$

ここで, ${ }_{c} \varepsilon_{t}={ }_{c} \sigma_{t} / E_{c}, \quad{ }_{k} \varepsilon_{c}={ }_{c} M\left(h-{ }_{c} X\right) / E_{k c} I$

3) 端部曲げひび割れ荷重以後中央曲げひび割れ荷重以前

この段階は合成スラブ両端部上端のコンクリート部分に曲げひび 割れが生じた後, 中央部の型枠材に曲げひび割れが生じるまでを指 し, その間の合成スラブ両端部と中央部断面の応力状態およびひず み分布状態は図 7 に示寸。なお, その時の中央総たわみ量 $c \Delta_{j}$ は ${ }_{c} \Delta_{j}=_{c} \delta_{c r}+_{c} \delta_{j}$ で, $c \delta_{j}$ は端部ひび割れ荷重以後の中央たわみ量であ り, ${ }_{c} \delta_{j}=\Delta \delta \cdot j \quad(j=1 \sim r$ の整数值 $)$ とし, $\Delta \delta$ は中央たわみの増 分量である。ただし, $r$ は ${ }_{k} \sigma_{t}>_{k} \sigma_{b}$ になる時の值である。

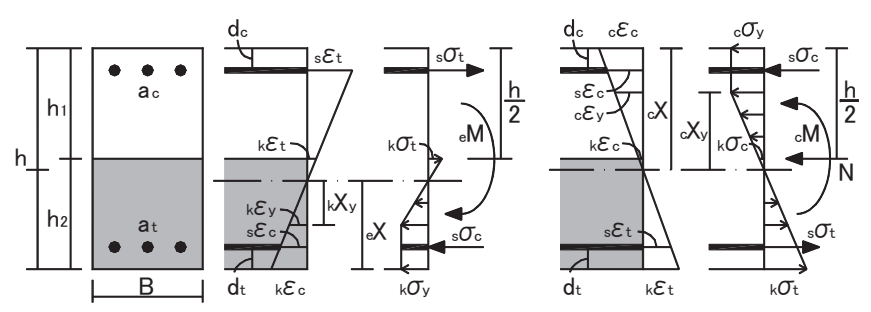

(a) 断面図 (b) 端部の応力度一ひずみ度分布 (c) 中央部の応力度一ひずみ度分布

図 7 端部曲げひび割れ以後の応力状態図 (a) つり合い式

図 7(b)から, 端部断面のつり合い式 $C-T=N$ より端部の中立軸 距離 $\mathrm{e} X$ についてまとめると次式になる。

$\left\{k \varepsilon_{y 1} / k \varepsilon_{c}-\left(k_{k} \varepsilon_{y 1} / k \varepsilon_{c}\right)^{2} / 2-\gamma / 2\right\}_{e} X^{2}+\left(\alpha m p_{t} h-\beta p_{t} h\right.$

$\left.+m p_{t} h_{s} \varepsilon_{y 1} / k \varepsilon_{c}-p_{t} h_{k} \varepsilon_{y 2} / k \varepsilon_{c}+\gamma h_{2}+\eta m p_{c} h-m p_{c} h_{s} \varepsilon_{y 2} / k \varepsilon_{c}\right)_{e} X$

$-\left(\alpha m p_{t} h d_{t}-\beta p_{t} h d_{t}+\gamma h_{2}^{2} / 2+\eta m p_{c} h d_{c}\right)=N_{e} X / E_{k} B_{k} \varepsilon_{c}$

$$
\begin{array}{ll}
\text { ただし, } & { }_{k} \varepsilon_{c} \geqq_{k} \varepsilon_{y} \rightarrow{ }_{k} \varepsilon_{y 1}={ }_{k} \varepsilon_{y} \\
& { }_{k} \varepsilon_{c}<{ }_{k} \varepsilon_{y} \rightarrow{ }_{k} \varepsilon_{y 1}=k \varepsilon_{c} \\
& { }_{s} \varepsilon_{c} \geqq_{s} \varepsilon_{y} \rightarrow \alpha=\beta=0, \quad{ }_{k} \varepsilon_{y 2}={ }_{k} \varepsilon_{y}, \quad{ }_{s} \varepsilon_{y 1}={ }_{s} \varepsilon_{y} \\
& { }_{s} \varepsilon_{c}<_{s} \varepsilon_{y} \rightarrow \alpha=\beta=1, \quad k \varepsilon_{y 2}={ }_{s} \varepsilon_{y 1}=0 \\
& { }_{s} \varepsilon_{t} \geqq_{s} \varepsilon_{y} \rightarrow \eta=0, \quad{ }_{s} \varepsilon_{y 2}={ }_{s} \varepsilon_{y} \\
& { }_{s} \varepsilon_{t}<_{s} \varepsilon_{y} \rightarrow \eta=1, \quad{ }_{s} \varepsilon_{y 2}=0 \\
& { }_{k} \sigma_{t}>_{k} \sigma_{b} \rightarrow \gamma=0 \\
& { }_{k} \sigma_{t} \leqq_{k} \sigma_{b} \rightarrow \gamma=1
\end{array}
$$

(b) 面内圧縮力の誘導

端部曲げひび割れ以後, 端部断面が回転を始め, 図 8 に示すよう に左半分の変形状態を考えると, 試験体の回転によって試験体は両 端部の拘束フレームを押し広げるため, その反作用として試験体の 断面内には面内圧縮力が生じる。この場合中央部断面には型枠材に 曲げひび割れが生じていないので弾性状態である。すなわち，ひび 割れによって生じる端部断面の材軸線上のあき $e e$ は端部回転によ る材軸長さ $e_{e} i^{\prime}{ }^{\prime} i^{\prime}$ の長さから回転前の材軸長さ $e_{e} i_{c} i^{\prime}$ を引いたもの である。回転前の材軸長さは三平方の定理より，中央たわみによる 水平方向の縮み量 $e_{d}$ と面内圧縮力による水平方向の縮夕量 $e_{c}$ を差 し引いた長さとたわ量 ${ }_{c} \Delta_{j}$ から求める。なお， $K$ は面内圧縮力に よる拘束フレームの伸び量と試験体の縮み量の割合を表す係数であ る。よって, 求める端部のあき $e e$ は次式になる。

$$
e e=\sqrt{\left(\frac{L}{2}+K e_{c}\right)^{2}+{ }_{c} \Delta_{j}^{2}}-\sqrt{\left(\frac{L}{2}-e_{c}-e_{d}\right)^{2}+{ }_{c} \Delta_{j}^{2}}
$$

高次の微小量を除いて整理すると下式になる。

$$
e^{e}=K e_{c}+e_{c}+e_{d}+\frac{2_{c} \Delta_{j}^{2}}{L}
$$

ここで $e_{e} e=\left(h / 2-{ }_{e} X\right) 2_{c} \delta_{j} / L, \quad e_{c}=N L / 2 A E_{c}, \quad e_{d}={ }_{c} \Delta_{j}{ }^{2} / L$ を式(12)

に代入し, 面内圧縮力 $N$ についてまとめると

$$
N=\frac{2 A E_{c}\left\{{ }_{c} \delta_{j}(h-2 e X)-{ }_{c} \Delta_{j}^{2}\right\}}{(1+K) L^{2}}
$$

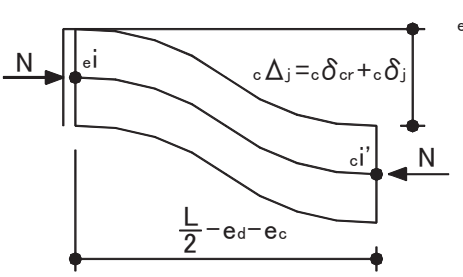

(a) 材軸方向の弾性縮み時の変形状態

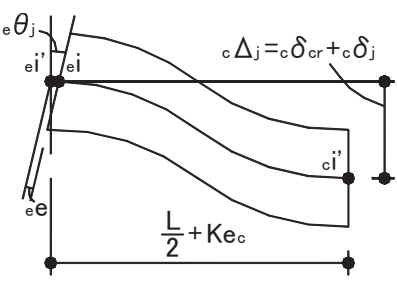

(b) 端部ひび割れ以後の変形状態

図 8 端部曲げひび割れ以後の変形状態図

(c) 端部中立軸距離の誘導

上述の式(13)を式(10)に代入して, 端部中立軸距離 $e_{e} X$ につてま 
とめると

$\left\{k \varepsilon_{y 1} /{ }_{k} \varepsilon_{c}-\left({ }_{k} \varepsilon_{y 1} /{ }_{k} \varepsilon_{c}\right)^{2} / 2-\gamma / 2\right\}_{e} X^{2}+\left\{\alpha m p_{t} h-\beta p_{t} h\right.$

$+m p_{t} h_{s} \varepsilon_{y 1} /{ }_{k} \varepsilon_{c}-p_{t} h_{k} \varepsilon_{y 2} /{ }_{k} \varepsilon_{c}+\gamma h_{2}+\eta m p_{c} h-m p_{c} h_{s} \varepsilon_{y 2} /{ }_{k} \varepsilon_{c}$

$\left.+4 A E_{c}\left(\Delta-\delta_{c r}\right) /(1+K) L^{2}\right\}_{e} X-\left[\alpha m p_{t} h d_{t}-\beta p_{t} h d_{t}+\gamma h_{2}^{2} / 2\right.$

$\left.+\eta m p_{c} h d_{c}-2 A E\left\{h\left(\Delta-\delta_{c r}\right)-\Delta^{2}\right\} /(1+K) L^{2}\right]=0$

(d) 曲げモーメントの算定式

よって, 端部断面に作用する曲げモーメント $e M$ は次式で求まる。

$e_{e} M=B E_{k k} \varepsilon_{c}\left[\left(k_{k} \varepsilon_{y 1} /{ }_{k} \varepsilon_{c}\right)_{e} X\left(h / 2-{ }_{e} X / 2\right)\right.$

$-\left({ }_{k} \varepsilon_{y 1} /{ }_{k} \varepsilon_{c}\right)^{2}{ }_{e} X\left\{h / 2-{ }_{e} X+\left(k \varepsilon_{1} / k_{k} \varepsilon_{C}\right)_{e} X / 3\right\} / 2$

$+\alpha m p_{t} h\left(e X-d_{t}\right)\left(h / 2-d_{t}\right) / e X-\beta p_{t} h\left(e X-d_{t}\right)\left(h / 2-d_{t}\right) / e_{e} X$

$+m p_{t} h_{s} \varepsilon_{y 1}\left(h / 2-d_{t}\right) / k_{k}-p_{t} h_{k} \varepsilon_{y 2}\left(h / 2-d_{t}\right) / k_{k} \varepsilon_{c}$

$+m p_{c} h_{s} \varepsilon_{y 2}\left(h / 2-d_{c}\right) /{ }_{k} \varepsilon_{c}+\eta m p_{c} h\left(h-{ }_{e} X-d_{c}\right)\left(h / 2-d_{c}\right) / e_{e} X$

$\left.-\gamma\left(h_{2}-e X\right)^{2}\left(h / 2-e_{e} X / 3-2 h_{2} / 3\right) / 2 e_{e} X\right]$

(e) 中央曲げモーメントの誘導

(15)

中央部断面は型枠材を使用しているため, まだ曲げひび割れは生 じてなく, スラブの変形状態は左右対称になっている。ここでは, その左半分の変形状態と断面応力状態を取り上げると図 9 のように なる。これにたわみ角法を用いると次式のようにまとまる。

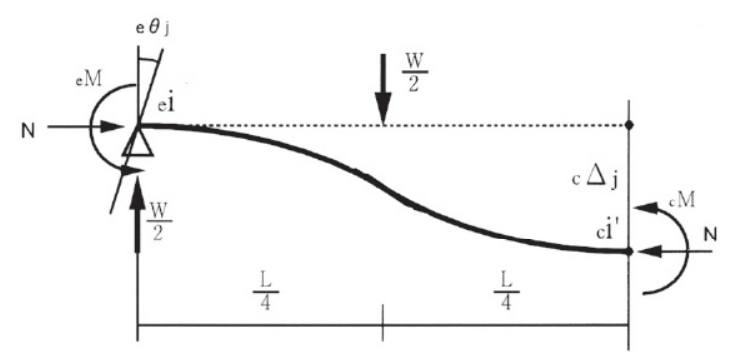

図 9 端部曲げひび割れ以後のつり合い図

$$
\begin{aligned}
{ }_{e} M & =-\frac{2 E_{c} I_{e}\left(2 e_{e} \theta-{ }_{c} \theta-3 R\right)}{(L / 2)+{ }_{e} C} \\
{ }_{c} M & =-\frac{2 E_{c} I_{c}\left(2{ }_{c} \theta-{ }_{e} \theta-3 R\right)}{(L / 2)+{ }_{c} C}
\end{aligned}
$$

ここで ${ }_{c} \theta=0$ から式(16)を ${ }_{e} \theta$ にいてまとめると

$$
{ }_{e} \theta=\frac{3 R}{2}-\frac{(L / 2)(e M+e C)}{4 E_{c e} I}
$$

式(18)を式(17)に代入し, さらに $R={ }_{c} \Delta_{j} /(L / 2)$ とおくと

$$
{ }_{c} M=\frac{{ }_{c} I\left(e_{e} M+{ }_{e} C\right)}{2 e_{e} I}+\frac{3 E_{c c} I_{c} \Delta_{j}}{(L / 2)^{2}}-{ }_{e} C
$$

ここで ${ }_{e} C=-3 W_{j} L / 32,{ }_{c} C=-W_{j} L / 32$ を式(19)に入れると

$$
{ }_{c} M=\frac{{ }_{c} I_{e} M}{2_{e} I}+\frac{3 E_{c c} I_{c} \Delta_{j}}{(L / 2)^{2}}+\frac{W_{j} L\left(1-3_{e} I / 2_{c} I\right)}{32}
$$

左半分の ${ }_{c} i$ 点に関するつり合いより

$$
\begin{array}{r}
-{ }_{e} M-{ }_{c} M+N_{c} \Delta_{j}+\frac{W_{j} L}{8}=0 \\
\text { よって } W_{j}=\frac{8\left({ }_{e} M+{ }_{c} M-N_{c} \Delta_{j}\right)}{L}
\end{array}
$$

式(21)を式(20)に代入してまとめると, 中央部曲げモーメント ${ }_{c} M$ は次式で表される。
${ }_{c} M=\left[\left\{{ }_{c} I / 2 e_{e} I+\left(1-3_{c} I / 2_{e} I\right) / 4\right\}_{e} M+\left\{3 E_{c c} I /(L / 2)^{2}\right.\right.$

$$
\left.\left.-\left(1-3_{c} I / 2_{e} I\right) N / 4\right\}_{c} \Delta_{j}\right] /\left\{1-\left(1-3_{c} I / 2 e_{e} I\right) / 4\right\}
$$

以上求めた式(13), 式(15), 式(22)を式(21)に代入すると, 曲げひ び割れ以後の ${ }_{c} \Delta_{j}$ 時の荷重 $W_{j}$ が求まる。

3) 中央曲げひび割れ以後終局耐力まで

この段階は図 10 のように端部と中央部の型枠材に曲げひび割れ が発生した場合であり，その変形状態は左半分が剛体回転すると考 えて中立軸距離と曲げモーメントを誘導する。

(a) 端部のつり合い式

この段階の端部のつり合い式 $C-T=N$ による, 端部の中立軸距 離 $e X$ と曲げモーメント $e M$ との式は前段階の式(14), 式(15)と全く 同じになるので，ここでは省略する。
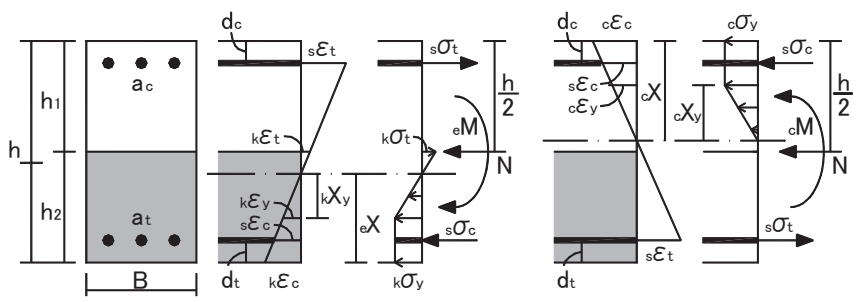

(a) 断面図 (b) 端部の応力度一ひずみ度分布 (c) 中央部の応力度一ひずみ度分布

図 10 中央曲げひび割れ以後最終耐力時までの応力状態図

(b) 中央部のつり合い式

図 10 から中央部のつり合い式 $C-T=N$ より, 中央部断面の中立 軸距離 $c X$ と曲げモーメント $c M$ を求めると式(23), 式(24)になる。 $\left\{\varepsilon_{c y 1} /{ }_{c} \varepsilon_{c c}-\varepsilon_{c y 1}{ }^{2} / 2_{c} \varepsilon_{c c}{ }^{2}+\gamma(k-1) / 2\right\}_{c} X^{2}+\left(\alpha n p_{c} h-\eta p_{c} h\right.$

$+\beta n p_{t} h-n p_{t} h_{s} \varepsilon_{y 1} / k_{k} \varepsilon_{c}-p_{t} h_{k} \varepsilon_{y 2} / k \varepsilon_{c}+\gamma h_{2}+\eta m p_{c} h$

$\left.-m p_{c} h_{s} \varepsilon_{y 2} / k \varepsilon_{c}\right)_{e} X-\left(\alpha m p_{t} h d_{t}-\beta p_{t} h d_{t}+\gamma h_{2}^{2} / 2\right.$

$\left.+\eta m p_{c} h d_{c}\right)=N_{e} X / E_{k} B_{k} \varepsilon_{c}$

${ }_{c} M=\left(E_{c} B_{c} \varepsilon_{c c} /{ }_{c} X\right)\left\{\varepsilon_{c y 1} X^{2}\left(h / 2-{ }_{c} X / 2\right) /{ }_{c} \varepsilon_{c c}\right.$

$-\varepsilon_{c y 1}{ }^{2}{ }_{c} X^{2}\left(h / 2-{ }_{c} X+3{ }_{c} \varepsilon_{c c}\right) / 2{ }_{c} \varepsilon_{c c}{ }^{2}$

$-\gamma(k-1)\left({ }_{c} X-h_{1}\right)^{2}\left(h / 2-{ }_{c} X / 3-2 h_{1} / 3\right) / 2$

$+\alpha n p_{c} h\left({ }_{c} X-d_{c}\right)\left(h / 2-d_{c}\right)+\beta n p_{t} h\left(h-{ }_{c} X-d_{t}\right)\left(h / 2-d_{t}\right)$

$+n p_{t} h\left(h / 2-d_{t}\right) \varepsilon_{s y 2} /{ }_{c} \varepsilon_{c c}+n p_{c} h\left(h / 2-d_{c}\right) \varepsilon_{s y 1} /{ }_{c} \varepsilon_{c c}$

$\left.-p_{c} h\left(h / 2-d_{c}\right) \varepsilon_{s y 1} / c \varepsilon_{c c}\right\}$

ただし,${ }_{c} \varepsilon_{c c} \geqq \varepsilon_{c y} \rightarrow \varepsilon_{c y 1}=\varepsilon_{c y}$

$$
\begin{aligned}
& { }_{c} \varepsilon_{c c}<\varepsilon_{c y} \rightarrow \varepsilon_{c y 1}={ }_{c} \varepsilon_{c c} \\
& { }_{c} \varepsilon_{s c} \geqq \varepsilon_{s y} \rightarrow \varepsilon_{s y 1}=\varepsilon_{s y}, \quad \alpha=0 \\
& { }_{c} \varepsilon_{s c}<\varepsilon_{s y} \rightarrow \varepsilon_{s y 1}=0, \quad \alpha=1 \\
& { }_{c} \varepsilon_{s c} \geqq \varepsilon_{c y} \rightarrow \varepsilon_{c y 2}=\varepsilon_{c y}, \quad \eta=0 \\
& { }_{c} \varepsilon_{s c}<\varepsilon_{c y} \rightarrow \varepsilon_{c y 2}=0, \quad \eta=1 \\
& { }_{c} \varepsilon_{s t} \geqq \varepsilon_{s y} \rightarrow \varepsilon_{s y 2}=\varepsilon_{s y}, \quad \beta=0 \\
& { }_{c} \varepsilon_{s t}<\varepsilon_{s y} \rightarrow \varepsilon_{s y 2}=0, \quad \beta=1 \\
& { }_{c} X \geqq h_{1} \rightarrow \gamma=1, \quad{ }_{c} X<h_{1} \rightarrow \gamma=0
\end{aligned}
$$

(c) 面内圧縮力の誘導

図 11 の合成スラブ左半分の変形状態より, 端部と中央部のあき $\left(e e+{ }_{c} e\right)$ は式(11)と同様にして求める。すなわち, 中央ひび割れ以後 の端部と中央部の材軸長さ $e_{i}{ }^{\prime}{ }_{c} i^{\prime \prime}$ から中央ひび割れ以前の中央たわ み ${ }_{c} \Delta_{j}$ 時の材軸長さ $i^{\prime}{ }_{c} i^{\prime \prime}$ を引けば端部と中央部のあき $\left(e e+{ }_{c} e\right)$ は 次式のように求まる。 


$$
e_{e} e+{ }_{c} e=\sqrt{\left(\frac{L}{2}+K e_{c}\right)^{2}+{ }_{c} \Delta_{j}^{2}}-\sqrt{\left(\frac{L}{2}-e_{c}-e_{d}\right)^{2}+{ }_{c} \Delta_{r}{ }^{2}}
$$

高次の微小量を除いて整理すると下式になる。

$$
e e+{ }_{c} e=k e_{c}+e_{c}+e_{d}+\frac{c^{\Delta_{j}}{ }^{2}-{ }_{c} \Delta_{r}{ }^{2}}{L}
$$

ここで $e_{e}=\left(h / 2-_{e} X\right) 2_{c} \delta_{j} / L, \quad{ }_{c} e=\left(h / 2-{ }_{e} X\right) 2\left({ }_{c} \delta_{j}-{ }_{c} \delta_{r}\right) / L$,

$e_{c}=N L / 2 A E_{c}, \quad e_{d}={ }_{c} \Delta_{r}{ }^{2} / L$ を式(25)に代入し, 面内圧縮力 $N$ につい てまとめると

$$
N=\frac{2 A E_{c}\left\{\left(2 h-{ }_{e} X-{ }_{c} X\right)\left({ }_{c} \delta_{j}-{ }_{c} \delta_{r}\right)-\left(h / 2-{ }_{c} X\right) 2_{c} \delta_{r} / L-{ }_{c} \Delta_{j}{ }^{2}\right\}}{(1+K) L^{2}}
$$

ここで, $A$ : 合成スラブの圧縮断面積, ${ }_{c} \delta_{r}$ : 中央曲げひび割れ時 点の中央たわみ量, $c \delta_{j}(j: r+1, r+2, \cdots)$ : 中央ひび割れ以 後のたわみ量
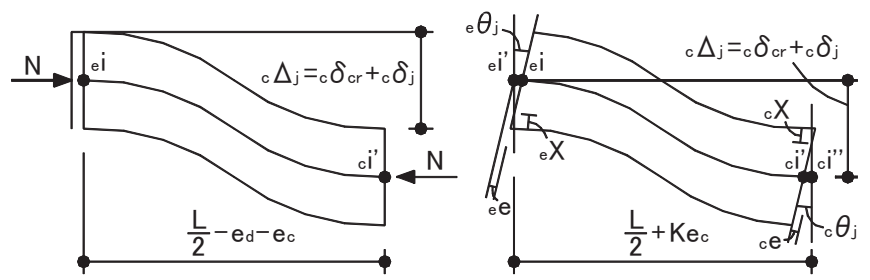

(a) 材軸方向の弾性縮夕時の変形状態

(b) 中央ひび割れ以後の変形状態

図 11 中央曲げひび割れ以後最終耐力時までの変形状態図

\section{(d) 中立軸決定式の誘導}

以上求めた式(15), 式(23)および式(27)より ${ }_{c} X,{ }_{e} X$ に関してまとめ れば ${ }_{c} X, e X$ に関する 4 次方程式になり, これを解くことによっ て中央および端部の中立軸距離を求め得る。これを式(15), 式(24) に代入すると，端部および中央部の曲げモーメントが求まる。 （e）中央曲げひび割れ以後の荷重の算定式

図 9 の ${ }_{c} i^{\prime}$ 点のつり合い式から求める荷重 $W$ は次式で求められる。

$$
W_{j}=\frac{8\left(e M+{ }_{c} M-N_{c} \Delta_{j}\right)}{L}
$$

\section{4. 検討に用いる試験体の実験概要}

3 章で誘導した解析曲線式の妥当性を検討するために, 過去に実 験を行った各種型枠材を用いた合成スラブの試験体を用いる。ここ では，検討に用いた合成スラブ試験体の概要について述べる。

\section{1 試験体}

合成スラブ試験体は図 12(a)〜 (c)に示す 3 種類の型枠材（FM30, FM75, FM100) の上に, 図 13(a)〜(d)のようにトップコンクリート を打込んだ断面と試験体長さ $280 \mathrm{~cm}$, 両端に $20 \mathrm{~cm}$ の梁を設けた全長 $320 \mathrm{~cm}$ の合成スラブである。この各試験体を FM3010, FM3030, FM7510，FM10005 と名付ける。なお，ここで用いた型枠材は高曲 げ無機材料を用いて押し出し成形によって作製している。各試験体 数は若材令 $(3$ 日強度 $) \cdot$ 標準材令 $(28$ 日強度）とも 2 体ずつ計 16 体である。

\section{2 材料の力学特性}

合成スラブに用いた若材令・標準材令のトップコンクリートは表 1 の条件で調合した生コンクリートを使用した。主筋および補強筋

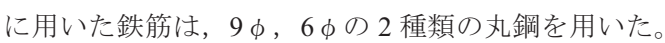

合成スラブに用いた型枠材の素材と型枠材の 2 点均等載荷で行っ た曲げ試験の曲げ応力度一ひずみ度曲線は図 14 に示した。また別に $\phi 20$ で長さ $30 \mathrm{~cm}$ の棒を用いて引張試験と圧縮試験を行った。そ の力学的性質は表 2 に示した。

以上示したコンクリートおよび鉄筋等の材料の力学的性質につい ては表 3, 表 4 に示した。

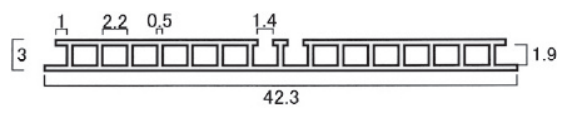

(a) FM30

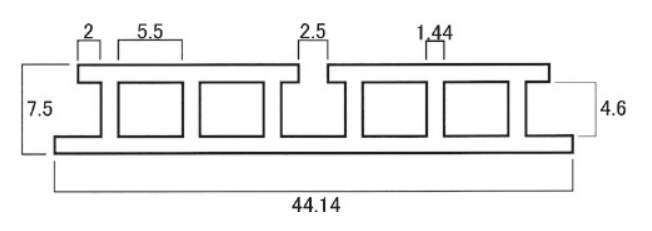

(b) FM75

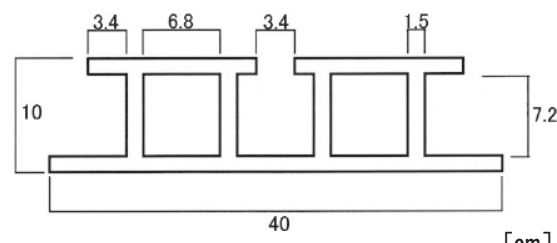

(c) FM100 $[\mathrm{cm}]$

図 12 使用型枠材の形状と種類

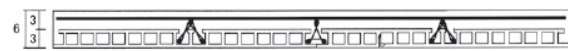

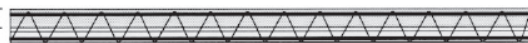

(a) FM3010
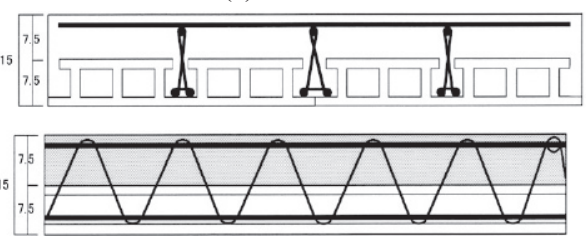

(c) FM7510

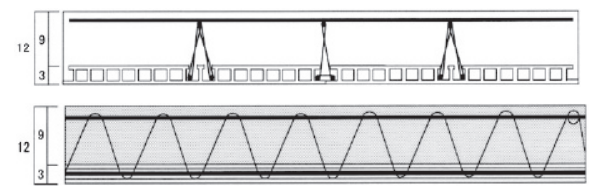

(b) FM3030

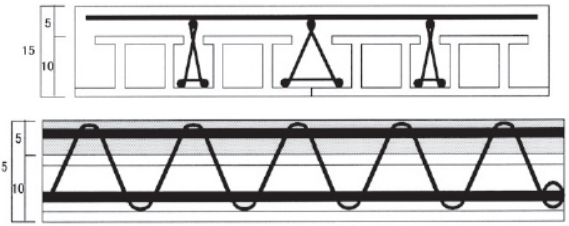

(d) FM10005

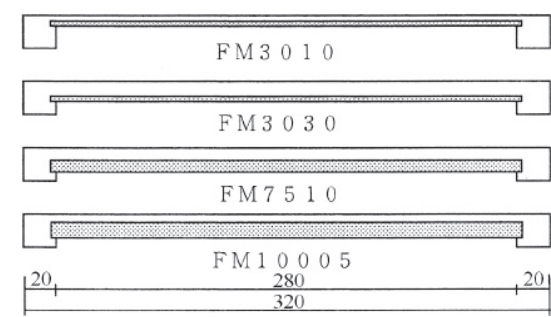

$[\mathrm{cm}]$

図 13 試験体の断面と配筋および形状図（上：断面図，下：配筋図） 


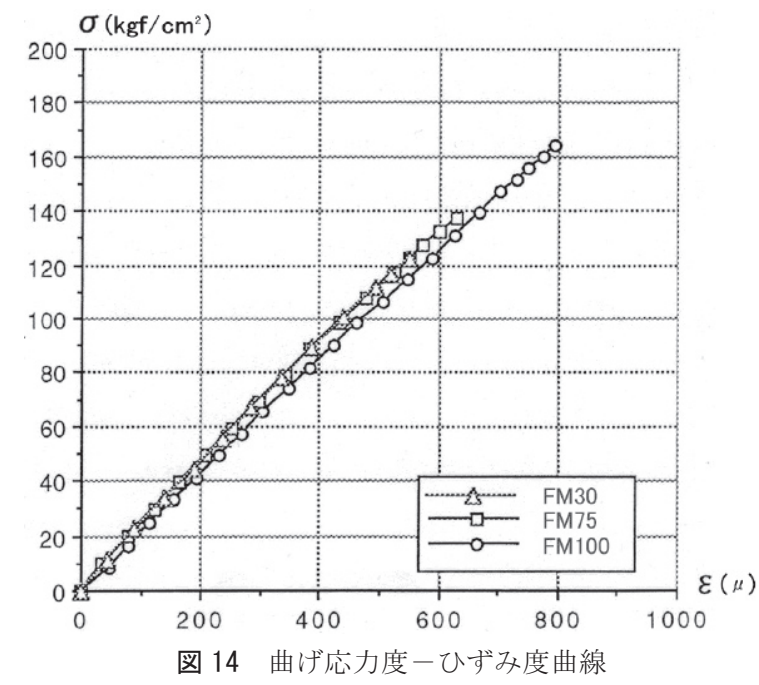

表 1 生コンクリートの調合表

\begin{tabular}{|c|c|c|c|c|}
\hline $\begin{array}{c}\text { コンクート 强度 } \\
\mathrm{kg} / \mathrm{cm}\end{array}$ & $\begin{array}{c}\text { 水さメ゙ } \\
\text { 比 }\end{array}$ & $\begin{array}{c}\text { 又ラン } \\
\mathrm{cm}\end{array}$ & $\begin{array}{l}\text { 粗骨材以 } \\
\text { 最大寸法 }\end{array}$ & $\begin{array}{l}\text { 細骨材の } \\
\text { 最大寸法 }\end{array}$ \\
\hline 255 & $65 \%$ & 18 & $20 \mathrm{~mm} \mathrm{~L}$ ○下 & 5 пाп1 \\
\hline
\end{tabular}

\section{3 実験方法}

実験は図 15 に示すように, 試験体両端部の拘束条件を得るために 鋼製拘束フレームに試験体を扦入 , 試験体両端部の梁と拘束フレ 一ムの隙間に超石膏を注入して試験体と拘束フレームの一体性を得 た。載荷方法は図 15 のように 4 等分割線の均等 2 点載荷とし, 最終 荷重まで単純漸増載荷で行った。

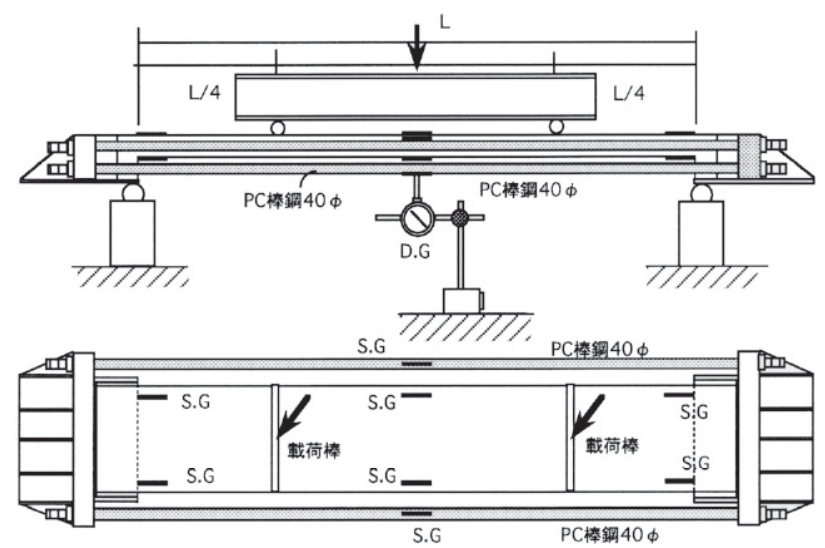

図 15 鋼製拘束フレームと載荷方法

\section{5. 実験結果}

4 章のように各合成スラブの耐力実験を行った結果, 最終耐力時 の試験体の代表的な破壊状態を図 16 の(a)〜(h)に示した。以下では, 各試験体の破壞に至るまでのひび割れ伸展状態について述べる。

図(a)(b)はFM3010 の若材令・標準材令である。両試験体とも，ま ず両端部の上端にひび割れが発生し, 荷重増加に伴って中央下部に も発生, 続いて端部の型枠材にも亀裂が伸展寸る。終局強度付近で, 中央部と端部においてトップコンクリートと型朹材の境界面に剥離 ひび割れが生じた。その後, あまり荷重が増加せず変形のみ伸展し た。図(c)(d)は FM3030 の若材令・標準材令である。この図から分か るように，ひび割れ伸展状態はほぼ FM3010 と同様であるが，若材
表 2 型枠材の力学特性

\begin{tabular}{|c|c|c|c|c|}
\hline 型枠材 & 曲げ強度 & 圧縮強度 & 引張強度 & 曲げヤング繁数 \\
\hline 種 類 & $\mathrm{kgf} / \mathrm{Gm}$ & $\mathrm{kgf} / \mathrm{cm}$ & $\mathrm{kg} / \mathrm{cm}$ & $\mathrm{kg} / \mathrm{cm}$ \\
\hline FM30 & 139 & 1389 & 105 & 247000 \\
\hline FM75 & 132 & 772 & 122 & 232000 \\
\hline Fll1 00 & 158 & 806 & 131 & 223000 \\
\hline
\end{tabular}

表 3 鉄筋の力学的特性

\begin{tabular}{|c|c|c|c|}
\hline $\begin{array}{ll}\text { 銑 } & \text { 筋 } \\
\text { 種 } & \text { 類 }\end{array}$ & $\begin{array}{c}\text { 降代強度 } \\
\mathrm{kg} / \mathrm{g} \text { 而 }\end{array}$ & $\begin{array}{c}\text { 引張强度 } \\
\mathrm{kg} / \mathrm{col}\end{array}$ & 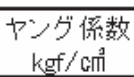 \\
\hline$\phi \theta$ & 4863 & 6223 & 2100000 \\
\hline$\phi 6$ & 3392 & 4376 & 2100000 \\
\hline
\end{tabular}

表 4 コンクリートの力学的特性

\begin{tabular}{|c|c|c|c|c|}
\hline $\begin{array}{l}\text { 試験体 } \\
\text { 種 類 }\end{array}$ & $\begin{array}{l}\text { 材 } \\
\text { 令 }\end{array}$ & $\begin{array}{c}\text { 圧縮強度 } \\
\mathrm{kg} / \mathrm{cm}\end{array}$ & $\begin{array}{c}\text { 引張強度 } \\
\mathrm{kg} / \mathrm{cm}\end{array}$ & $\begin{array}{c}\text { アグ倷数 } \\
\mathrm{kg} / \mathrm{cm}\end{array}$ \\
\hline \multirow{2}{*}{ FW:3010 } & 3 & 117 & 11 & 154000 \\
\hline & 28 & 312 & 31 & 227000 \\
\hline \multirow{2}{*}{ FMBO30 } & 3 & 123 & 13 & 172000 \\
\hline & 28 & 263 & 31 & 262000 \\
\hline \multirow{2}{*}{ FW17510 } & 3 & 112 & 14 & 18,3000 \\
\hline & 28 & 246 & 27 & 330000 \\
\hline \multirow{2}{*}{ FM11 0005} & 3 & 131 & 14 & 170000 \\
\hline & 28 & 316 & 20 & 252000 \\
\hline
\end{tabular}

令・標準材令とも中央ひび割れが生じた後, 中央上部のコンクリー 卜の圧壊で最終耐力に至った。図(e)〜(h)は FM7510, FM10005 の若 材令・標準材令である。これらの試験体も，基本的には上述と同様 であるが，ただ型枠材が厚いため，端部ひび割れが生じた後のひび 割れ伸展状態は型枠材上部に沿って生じる傾向がみられた。このこ とは FM3010 のように端部型枠材にひび割れが生じないため引張抵 抗はなく, 圧縮抵抗のみと考えられる。最終的には 4 試験体とも両 端部の梁の水平せん断破壊で最終耐力に至った。

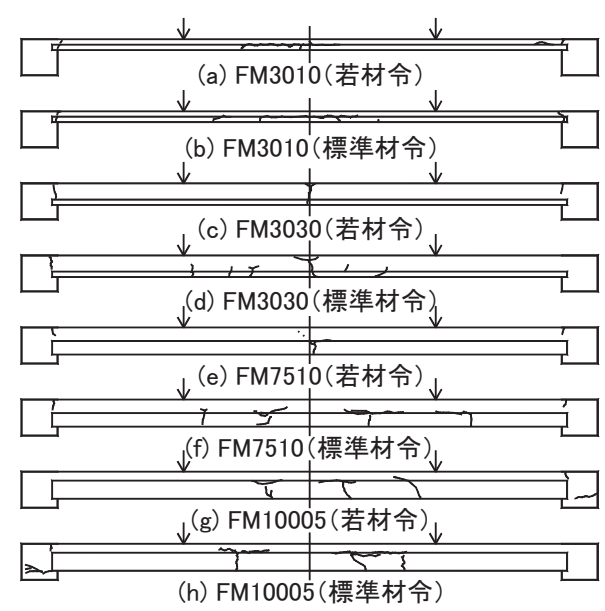

図 16 若材令と標準材令の最終破壊状態困

また，図 17(a)〜(d)には，上述試験体の荷重たわみ曲線（以後実 験曲線と称寸）を示した。なお，実験曲線と 3 章で求めた解析曲線 を比較検討するため解析曲線を各図中に併記した。また, 各試験体 の最大荷重実験值と解析值の比較を表 5 に示した。表 6 は, 合成ス ラブに用いた型枠材 FM30,FM75, FM100の素材・部材・合成スラ ブの曲げ強度の比較を表したものである。なお，計算に用いた断面 係数は，合成スラブのみ等価断面を考慮している。 


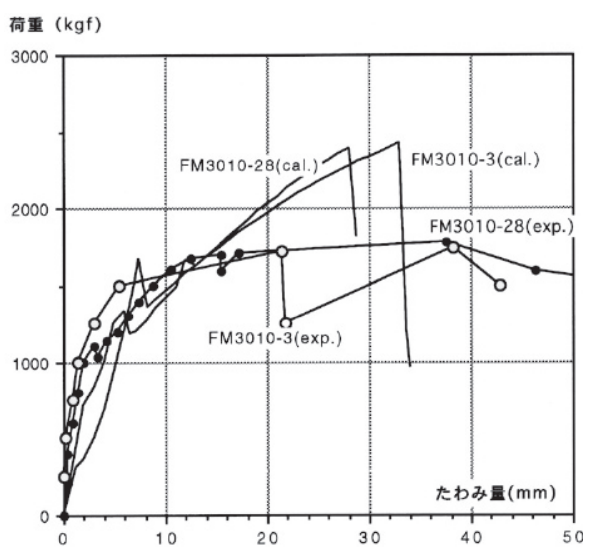

(a) FM3010

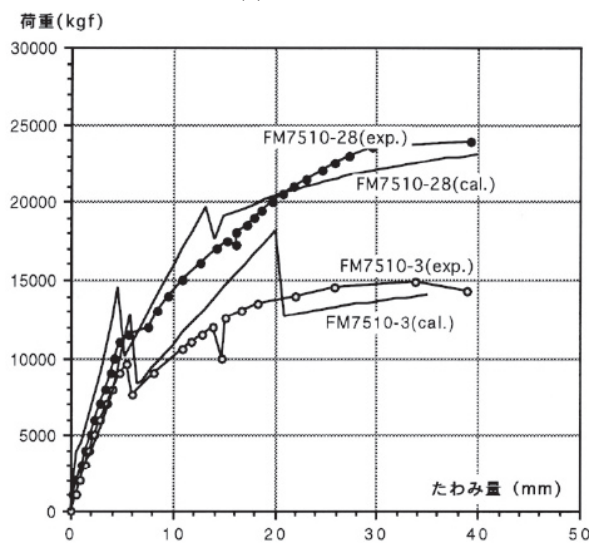

(c) FM7510

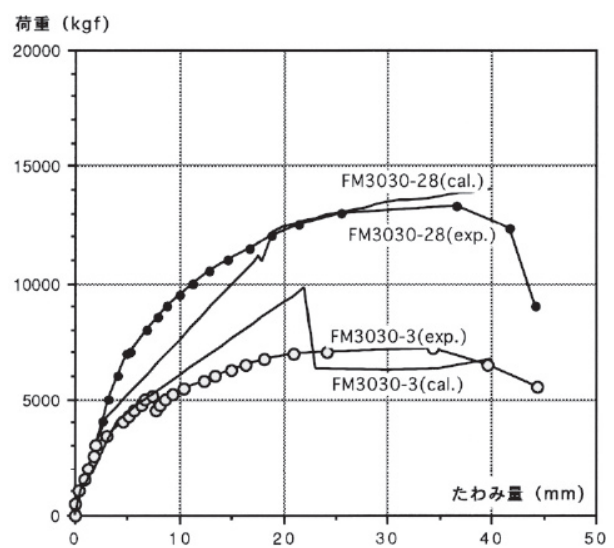

(b) FM3030

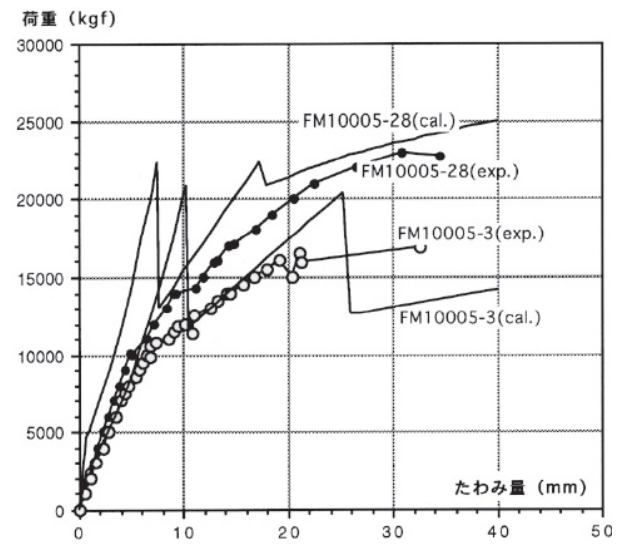

(d) FM10005

図 17 若材令・標準材令の荷重変形曲線比較図

表 5 最大荷重時の耐力比較

\begin{tabular}{|c|c|c|c|c|c|}
\hline $\begin{array}{l}\text { 試 験 体 } \\
\text { 種 類 }\end{array}$ & $\begin{array}{l}\text { 材 } \\
\text { 令 }\end{array}$ & $\begin{array}{l}\text { 番 } \\
\text { 号 }\end{array}$ & $\begin{array}{c}\text { 実験値 } \\
\mathrm{kgf}\end{array}$ & $\begin{array}{c}\text { 計算値 } \\
\mathrm{kgf}\end{array}$ & $\frac{\text { 実験値 }}{\text { 計算値 }}$ \\
\hline FM3010 & 3 & 1 & 1750 & 2424 & 0.72 \\
\hline \multirow{2}{*}{ FM3030 } & 3 & 1 & 7210 & 10005 & 0.72 \\
\hline & 3 & 2 & 7500 & 9966 & 0.75 \\
\hline \multirow{2}{*}{ FM7510 } & 3 & 1 & 14920 & 18221 & 0.82 \\
\hline & 3 & 2 & 12850 & 18503 & 0.69 \\
\hline \multirow{2}{*}{ FM1 0005} & 3 & 1 & 16700 & 20334 & 0.82 \\
\hline & 3 & 2 & 16820 & 20079 & 0.84 \\
\hline \multirow{2}{*}{ FM3010 } & 28 & 1 & 1785 & 2506 & 0.71 \\
\hline & 28 & 2 & 1840 & 2698 & 0.68 \\
\hline \multirow{2}{*}{ FM3030 } & 28 & 1 & 12070 & 14000 & 0.86 \\
\hline & 28 & 2 & 13250 & 14000 & 0.95 \\
\hline \multirow{2}{*}{ FM7510 } & 28 & 1 & 23900 & 23081 & 1.04 \\
\hline & 28 & 2 & 20200 & 23223 & 0.87 \\
\hline \multirow{2}{*}{ FM1 0005} & 28 & 1 & 23000 & 25001 & 0.92 \\
\hline & 28 & 2 & 19850 & 24169 & 0.82 \\
\hline
\end{tabular}

表 6 素材・部材・合成スラブの曲げ強度

\begin{tabular}{|c|c|c|c|c|c|}
\hline \multirow{2}{*}{ 合成入ラ7゙ } & \multirow{2}{*}{$\begin{array}{l}\text { 使 用 } \\
\text { 型枠材 }\end{array}$} & \multicolumn{4}{|c|}{ 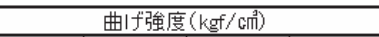 } \\
\hline & & 素材 & 型枠材 & 標準材命 & 若材令 \\
\hline FM3010 & FM30 & 185 & 139 & 90 & 43 \\
\hline FM3030 & FMBO & 185 & 139 & 92 & 33 \\
\hline FM7510 & FM75 & 239 & 132 & 98 & 64 \\
\hline FM1 0005 & FM100 & 282 & 158 & 72 & 46 \\
\hline
\end{tabular}

\section{6. 比較検討および考察}

以上の図 $17(\mathrm{a}) \sim(\mathrm{d})$ および表 5 , 表 6 より実験結果と解析結果の比 較から次のように考察できる。

\section{1 荷重たわみ曲線}

1) FM3010 型の場合

図 17(a)から分かるように, FM3010 型の若材令は中央ひび割れ荷 重までの実験曲線と大きな差が生じた。この原因は, 試験体厚が長
さに比べて非常に薄くコンクリート強度も小さいため, 試験体を拘 束フレームへ挿入中，端部上部に曲げひび割れが入り中央たわみ量 もかなり生じていたことにある。すなわち，この試験体は実験前す でに第 2 段階に入って実験開始と同時に面内力が発生しており, 他 の試験体のように弾性たわみが測定されなかったことによるものと 考える。それに対して，標準材令は比較的よく追随している。これ はほぼ解析仮定と同じ傾向のひび割れ伸展状態だったからといえる。 しかし, 中央ひび割れ以後, 実験曲線はほぼ水平に推移しているの に対し, 若干上昇傾向をみせている。この差は, 図 16(a)(b)のひび 割れ伸展状態からも分かるように試験体の中央部と端部の型枠材と トップコンクリート間に生じた剥離による影響によって剛性が低下 したためと考える。

2) FM3030 型の場合

図 17(b)から若材令・標準材令とも実験曲線と解析曲線は, 若干差 異はあるが比較的近似する傾向を示した。しかし，若材令の中央ひ び割れ後の曲線に差が生じている。この試験体のひび割れ状態は両 端部とも型枠材を避けてひび割れが伸展している。すなわち，端部 の型枠材はほとんど引張力を負担せず，圧縮力のみ負担すると考え る。それに対し，解析曲線は式中に型枠材の影響を取り込んでいる ため耐力上昇したものと考えられる。

3) FM7510，FM10005 型の場合

図 17(c)(d)の比較図から, 解析曲線のうち中央の型枠材に曲げひ び割れが生じるまでの荷重たわみ曲線は直線性のある上昇傾向を示 すが，実験曲線は図中のように端部曲げひび割れ以後，型枠材と卜 
ップコンクリートとも境界面に生じた剥離によって徐々に中央の曲 げ剛性が落ちるため滑らかな曲線となって解析曲線と差を生じた。 この差をなくするためには解析曲線に剥離の影響を考慮した曲げ剛 性を取り入れる必要がある。最終耐力は両端部に設けた梁幅が 20 $\mathrm{cm}$ と小さかったため, 梁とスラブの付け根部分の水平せん断破壊に よって耐力が急激に落ちた。そのため, 解析曲線の最終たわみは実 験結果と同様に水平せん断破壞で終了させた。しかし, 解析曲線は 全体的な傾向としては実験曲線をよく表しているといえる。

以上 1)2)3)の比較より, 解析曲線は実験曲線をよく表せたと考え る。しかし，第 2 段階で差を生じる傾向があり，これについては解 析曲線に境界面の剥離の影響を考慮に入れて改善していく必要があ る。

\section{2 最大荷重時の実験值と解析値の比較検討}

表 5 は最大荷重時の実験結果と解析結果の比較表である。これよ り最大荷重時では約 30\%程度の差異が出た。その原因は, 上述した ように境界面の剥離の影響を取り込んでいないためである。しかし， 合成スラブという異なる材質を考慮すると比較的合ったと考える。

\section{3 型枠材の曲げ強度}

図18 は表 6 に示寸型枠材から切り出した素材の曲げ強度を基準に して型枠材，合成スラブ（以後標準材令，若材令と称寸）に用いた 場合の型枠材の曲げ強度の低下についてまとめたものである。この 図から型枠材，標準材令および若材令の順で曲げ強度が低下してい ることが分かる。これは型枠材や合成スラブのように同じ素材であ っても形状変化, トップコンクリート厚やトップコンクリートから の吸水量およびトップコンクリートの収縮量等の影響によってかな り強度低下したと考えられる ${ }^{6}$ 。

また, 型枠材がトップコンクリートとの一体性が十分でない若材 令の場合でも，FM3010 や FM7510 の曲げ強度は素材強度の 22\%〜 $28 \%$ 程度となることから, トップコンクリート厚は型枠材厚と同じ 厚さに打つことが望ましい。

以上のことから, 型枠材を実用的に用いる場合は, 素材強度が大 きくても型枠材の使用目的によってかなり強度低下があるため, そ の点をよく考慮しておく必要がある。

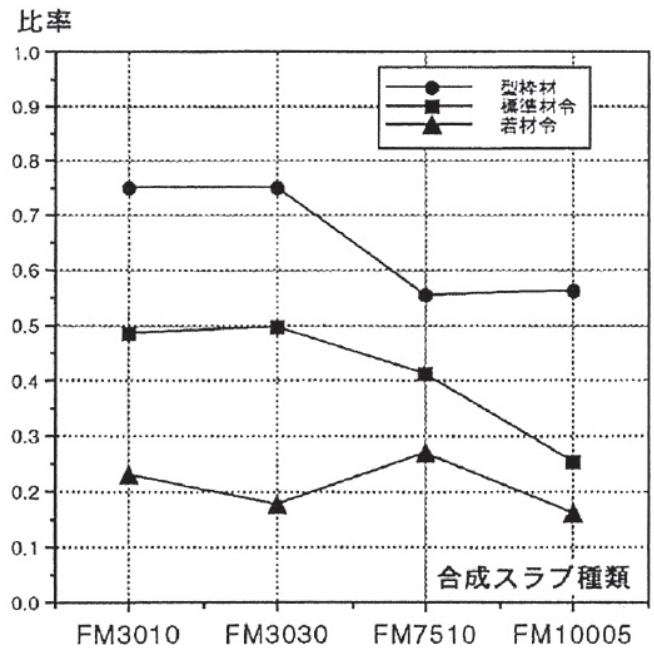

図 18 素材曲げ強度に対寸る型枠材曲げ強度比

\section{7. まとめ}

高曲げ強度を持つ打込み型枠材を用いた合成スラブは，両端を拘 束すれば若材令（3 日強度）でもかなり高い耐力を期待できること が分かった。特に，建設業界は従来 $3 \mathrm{~K}$ （きつい，污い，危険）のイ メージが強く, 熟練労働者の高齢化や技能工と呼ばれる腕の良い技 能労働者の確保が年々難しくなっている現状で, 打込み型枠を用い るスラブ工法は非常に有効な手段であると考えられる。

本研究は両端拘束一方向性合成スラブの解析曲線式にウェートを おいて報告したものである。

その結果，打込み型枠材の種類に関わらず合成スラブ厚の厚い実 用的な試験体は解析曲線と実験曲線が比較的よく合う傾向を示した このことから解析条件で提案した 3 段階方式は検証した範囲内では あるが妥当であることが確認された。しかし，トップコンクリート と打込み型枠材に生じた境界面の剥離の影響によって中央ひび割れ 荷重や両端部の型朹材ひび割れ荷重が実験曲線より解析曲線の方が 大きく出る傾向があり，今後はそれらの影響を考慮に入れて解析曲 線式を改善していく必要がある。

以上のことから，本解析方法はトップコンクリートと型枠材の境 界面の影響を取り入れていないが，合成スラブの実験曲線の傾向を ほぼ全体に渡って表している。したがって，本実験範囲内であるが 本解析方法は実用的な合成スラブの傾向を示寸一方法として充分適 用可能であると考える。

\section{謝辞}

本研究は，故馬場明生氏のご指導を賜りました。ここに謹んで感 謝申し上げます。また，実験資料は，建設省総合技術開発プロジェ クトの自動化適合型鉄筋コンクリート開発の一環で行われたものを 用いています。さらに, 日本化薬（株）及び（株）ノザワからは打 込み型枠等の資材を提供して頂きました。以上に対し深く謝意を表 します。

\section{参考文献}

1）森村 毅，在永末徳，馬場明生：自動化適合型鉄筋コンクリート構法の 開発(36)，床構造の開発，その７面内力を受ける打ち込み型枠スラブの モデル実験，日本建築学会大会学術講演梗概集（関東），A，pp.99-100, 1993.9

2) 村上雅則, 馬場明生, 森村 毅, 在永末徳 : 自動化適合型鉄筋コンクリ 一ト構法の開発(65)，床構造の開発，その 12 強軸方向に型枠材を用い た両端拘束一方向性合成スラブに関寸る実験的研究, 日本建築学会大会 学術講演梗概集 (東海)，A，pp.1005-1006，1994.9

3）黒田芳憲，馬場明生，森村 毅，在永末徳：自動化適合型鉄筋コンクリ 一ト構法の開発(66)，床構造の開発，その 13 弱軸方向に型枠材を用い た両端拘束一方向性合成スラブに関する実験的研究，日本建築学会大会 学術講演梗概集 (東海)，A，pp.1007-1008， 1994.9

4) 森村 毅，在永末徳，馬場明生：自動化適合型鉄筋コンクリート構法の 開発(67)，床構造の開発，その 14 強軸と弱軸方向に型枠材を用いた実 物大合成スラブの比較検討, 日本建築学会大会学術講演梗概集（東海）, A, pp.1009-1010, 1994.9

5) 藤原亮二, 森村 毅, 在永末徳 : 打込み型枠材を用いた両端拘束合成又 ラブの荷重変形特性に関する研究，日本建築学会大会学術講演梗概集（九 州), A-1, pp.351-352, 1998.9

6) 森村 毅, 在永末徳, 馬場明生 : 自動化適合型鉄筋コンクリート構法の 開発(13)，型枠・鉄筋構工法の開発，その 7 一体性スラブの乾燥収縮・ 付着およびせん断強度, 日本建築学会大会学術講演梗概集 (北陸), A, pp.807-808, 1992.8 